\title{
Changes in chemical attributes of a Fluvent cultivated with castor bean and irrigated with wastewater
}

\author{
Aurelir N. Barreto ${ }^{1}$, Joab J. V. R. do Nascimento ${ }^{2}$, Everaldo P. de Medeiros' ${ }^{1}$, \\ Janiny A. da Nóbrega ${ }^{3} \&$ Jose R. C. Bezerra ${ }^{1}$
}

\begin{abstract}
Agricultural use of wastewater is an alternative to increase water availability, especially in semiarid regions However, it may cause undesirable chemical changes in the soil. The aim of this study was to evaluate the influence of wastewater irrigation and castor bean (Ricinus communis L.) cultivation on the chemical attributes of a Fluvic Neosol. The experimental design was in a randomized block, in split-plot scheme, where the main plots were represented by the treatments of irrigation water and castor bean cultivation, and the subplots were the soil layers, with three replications. The treatments were T1 - wastewater irrigation + castor bean cultivation; T2 - mixture of supply water and wastewater (1:1 ratio) + castor bean cultivation; T3 - supply water irrigation + castor bean cultivation; and T4 - wastewater application, without castor bean cultivation. The depths of soil layers were $0-10,10-20,20-30,30-40$, and $40-50 \mathrm{~cm}$. At the end of study, the content of phosphorus, calcium, potassium, and organic matter increased mainly in the upper layers, and sodium increased in the deeper layers in the wastewater treatments, in comparison to the supply water irrigation. In T4, the disposal of wastewater increased the concentration of magnesium. The $\mathrm{pH}$ values, iron and zinc concentration did not statistically differ in the treatments.
\end{abstract}

Key words: reuse, nutrients, effluent, water management, Ricinus communis

\section{Alterações nos atributos químicos de um Neossolo Flúvico cultivado com mamoneira e irrigado com água residuária}

RESUMO

A utilização de água residuária na agricultura é uma alternativa de aumento da disponibilidade hídrica, sobretudo nas regiões semiáridas passíveis, no entanto, de causarem alterações químicas indesejáveis no solo. Objetivou-se, neste trabalho, avaliar os efeitos da aplicação de diferentes manejos de água nas características químicas de um Neossolo Flúvico cultivado com mamoneira (Ricinus communis L.). Instalouse um experimento em blocos casualizados com parcelas subdivididas enquanto as parcelas continham os seguintes tipos de manejo de água (T1 - irrigação com água residuária + cultivo de mamoneira; T2 - irrigação com uma mistura de água residuária e água de abastecimento, na proporção 1:1 (v/v) + cultivo de mamoneira; T3 - irrigação com água de abastecimento, + cultivo da mamoneira; T4 - aplicação de água residuária, sem cultivo de mamoneira) e nas subparcelas as faixas de profundidade $(0-10 ; 10-20 ; 20-30 ; 30-40$ e $40-50 \mathrm{~cm})$, com três repetições. Após a aplicação da água residuária no solo os teores de fósforo, cálcio, potássio e matéria orgânica, principalmente na camada superficial, e sódio, em profundidade, aumentaram significativamente, em comparação com a aplicação de água de abastecimento. No solo sem cultivo a disposição de água residuária aumentou a concentração de magnésio. Os valores de $\mathrm{pH}$, ferro e zinco não se alteraram.

Palavras-chave: reúso, nutrientes, efluente, manejo de água, Ricinus communis

\footnotetext{
Embrapa Algodão. Rua Oswaldo Cruz, 1143, Centenário, CP 174, CEP 58428-095, Campina Grande, PB. In memoriam. Fone:(83) 3182-4300. E-mail: everaldo.medeiros@embrapa.br, renato@cnpa.embrapa.br

${ }^{2}$ DAIC/IFPE. Av. Prof. Luiz Freire, n 500, Cidade Universitária, CEP 50070-540, Recife, PE. Fone: (81) 2125-1600. E-mail: joabjosemar@gmail.com ${ }_{3}^{3}$ UAEA/UFCG. Rua Aprígio Veloso, 882, Bairro Universitário, CEP 58429-900, Campina Grande, PB. Fone: (83) 9654-4768. E-mail: janinynobrega@gmail.com
} 


\section{INTRODUCTION}

Water scarcity is a worldwide concern, which is worsened by the increasing demand for various uses (Corwin \& Bradford, 2008). In spite of $18 \%$ of total world freshwater being located in Brazil, there are many national problems of water supply, mainly due to the heterogeneous geographical water distribution and inadequate management, that causes pollution, wastage, and overuse.

The use of wastewater for irrigation is a viable option to reduce the use of water resources and to increase the supply of quality water for more restrictive uses, such as drinking water (Tozé, 2006). Besides being a source of water, the wastewaster contains nutrients, organic matter, and soil conditioning agents, which promote the establishment of crops, and increase their productivity (Fonseca et al., 2007).

The organic matter in wastewater can improve soil aeration, infiltration rate, water storage, cation exchange capacity (CEC), as well as decrease the potential for soil erosion and increase the population of organisms which promotes plant growth (Tozé, 2006; Corwin \& Bradford, 2008; Arienzo et al., 2009). Moreover, this practice is an effective method to control pollution, avoiding the discharge of effluents into water bodies (Tozé, 2006).

Despite the benefits of wastewater in agriculture, its application can create environmental problems, as a consequence of some chemical and biological undesirable constituents (Tozé, 2006; Rusan et al., 2007). It has been observed under Brazilian soil and climatic conditions that this practice may affect the content of macro and micronutrients, organic matter, heavy metals, sodium, exchangeable sodium percentage (ESP), $\mathrm{pH}$, and CEC (Fonseca et al., 2007; Herpin et al., 2007; Duarte et al., 2008; Leal et al., 2009 a,b; Leal et al., 2010).

The magnitude of changes in soil chemical attributes depends mainly on local conditions, such as soil type, depth range, quality and quantity of used wastewaster in the system, and the kind of grown plant species (Corwin \& Bradford, 2008; Kiziloglu et al., 2008; Xu et al., 2010; Liang et al., 2010; Leal et al., 2010). These changes may result in significant impacts in the soil quality (Fonseca et al., 2005; Herpin et al., 2007), or may not (Varallo et al., 2010; Duan et al., 2010). Thus, the soil chemical attributes must be continuously monitored (Leal et al., 2009b). Fonseca et al. (2007) and Herpin et al. (2007) suggest that studies on the environmental impacts of wastewater disposal in soil, in different soil types and different cropping systems, under various climatic conditions, must be conducted to evaluate the environmental and economic impacts. Measurements of this kind allow the establishment of recommendations of use of wastewater, especially in Brazilian agroecosystems, in which this kind of information is still very rare.
The aim of this study was to evaluate the changes in the chemical attributes of several layers of a Fluvic Neosol under castor bean cultivation, in drainage lysimeters with different wastewater management strategies, under Brazilian semiarid conditions.

\section{Material And Methods}

The experiment was carried out in Campina Grande, Paraiba State, Brazil ( $\left.7^{\circ} 13^{\prime} 50^{\prime \prime} \mathrm{S}, 35^{\circ} 52^{\prime} 52^{\prime \prime} \mathrm{W}\right)$. The study was conducted in 12 drainage monolithic lysimeters, with the total depth of $1.0 \mathrm{~m}$ and diameter of $0.70 \mathrm{~m}$, built on the left bank of Bodocongó stream $\left(7^{\circ} 14^{\prime} 25^{\prime \prime} \mathrm{S}, 35^{\circ} 55^{\prime} 14^{\prime \prime} \mathrm{W}\right.$, elevation of $501 \mathrm{~m})$. The lysimeters were replaced to the experimental area of the Federal University of Campina Grande (UFCG) ( $7^{\circ}$ $12^{\prime} 52^{\prime \prime} \mathrm{S}, 35^{\circ} 54^{\prime} 25^{\prime}$ ' W, elevation of $528 \mathrm{~m}$ ).

The soil is a Eutrophic Fluvic Neosol (EMBRAPA, 2006), sandy loam, where castor bean was grown. The hydro-physical (Table 1) and chemical (Table 2) analyses of the soil before the experiment were carried out following methodologies recommended by EMBRAPA (1997).

Table 1. Hydro-physical attributes of Fluvic Neosol before treatment

\begin{tabular}{cc}
\hline Hydro-physical attribute & Value \\
Particle size $\mathrm{g} \mathrm{kg}^{-1}$ & \\
Sand & 754 \\
Silt & 135 \\
Clay & 111 \\
Soil bulk density $\left(\mathrm{kg} \mathrm{dm}^{-3}\right)$ & 1.50 \\
Soil particle density $\left(\mathrm{kg} \mathrm{dm}^{-3}\right)$ & 2.67 \\
Porosity (\%) & 43.8 \\
Tension (kPa) Moisture (\%) & \\
33,33 (field capacity) & 11.20 \\
1515 (wilting point) & 1.90 \\
\hline
\end{tabular}

The wastewater used in the experiment came from a stream that receives contributions from sewers and passes through the experimental area of the Academic Unit of Agricultural Engineering of UFCG. The wastewater was filtered with a nylon sieve $(\Phi=2.0 \mathrm{~mm})$ at the point of capture to remove coarse solids. The potable water came from the public water supply system of Campina Grande. Analyses of potable water and wastewater were performed according to methodologies recommended by APHA (1999) and the results are presented in Table 3.

Five seeds of castor bean (Ricinus communis L.) CV BRS Energy were sown in the lysimeters in the first fortnight of September 2007 and 15 days after germination, thinning was done, leaving only one plant per lysimeter. Irrigation was

Table 2. Chemical attributes of Fluvic Neosol before treatments

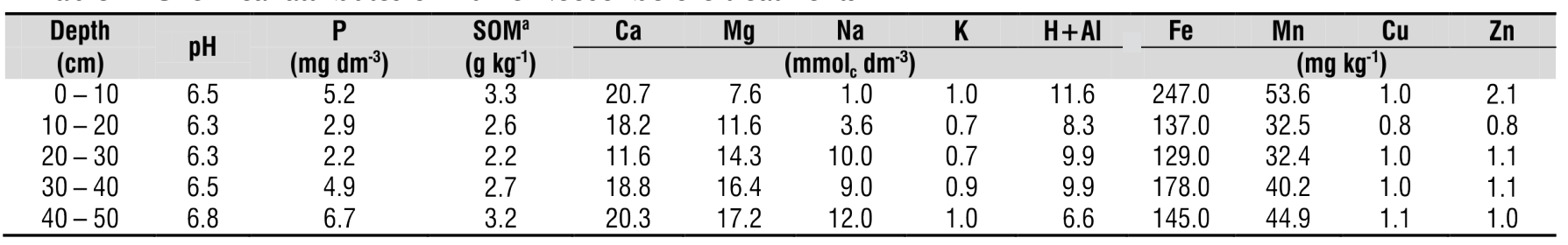

a Soil organic matter 
Table 3. Physical-chemical characteristics of the potable water and wastewater

\begin{tabular}{lcc}
\hline \multicolumn{1}{c}{ Parameter } & Wastewater & Potable water \\
pH & 6.98 & 7.23 \\
Alkalinity $\left(\mathrm{mg} \mathrm{CaCO}_{3} \mathrm{~L}^{-1}\right)$ & 552.00 & 145.98 \\
Hardness $\left(\mathrm{mg} \mathrm{CaCO}_{3} \mathrm{~L}^{-1}\right)$ & 341.14 & 143.05 \\
Electrical conductivity $\left(\mu \mathrm{S} \mathrm{cm}^{-1}\right)$ & 1585 & 502 \\
Total nitrogen $\left(\mathrm{mg} \mathrm{L}^{-1}\right)$ & 54.61 & $\mathrm{Bdl}^{\mathrm{a}}$ \\
Total solids $\left(\mathrm{mg} \mathrm{L}^{-1}\right)$ & 941.4 & $\mathrm{Bdl}^{\mathrm{a}}$ \\
Volatile solids $\left(\mathrm{mg} \mathrm{L}^{-1}\right)$ & 289.2 & $\mathrm{Bdl}^{\mathrm{a}}$ \\
Iron $\left(\mathrm{mg} \mathrm{L}^{-1}\right)$ & 0.090 & $\mathrm{Bdl}^{\mathrm{a}}$ \\
Manganese $\left(\mathrm{mg} \mathrm{L}^{-1}\right)$ & 0.030 & $\mathrm{Bdl}^{\mathrm{a}}$ \\
Cupper $\left(\mathrm{mg} \mathrm{L}^{-1}\right)$ & 0.004 & $\mathrm{Bdl}$ \\
Zinc $\left(\mathrm{mg} \mathrm{L}^{-1}\right)$ & 0.001 & $\mathrm{Bdl}$ \\
\hline
\end{tabular}

applied for 120 days until it reached a total of $1,000 \mathrm{~mm}$ of potable water and/or wastewater. Afterwards, irrigation was stopped because the castor bean had completed the development cycle.

The volumetric water content in the $0-60 \mathrm{~cm}$ layers was monitored every 2 days using a capacitance probe (model Diviner 2000). Irrigation was performed with manual randomized application of water, based on water demand of the crop.

The experiment was arranged in a completely randomized block design, in a split-plot scheme, with three replications. The treatments consisted of: T1 - Wastewater irrigation + castor bean cultivation; T2 - Wastewater and supply water mixture (1:1 proportion) + castor bean; cultivation T3 - Supply water irrigation + castor bean cultivation ; and $\mathrm{T} 4$ - wastewater application, without castor bean cultivation. The analysed depths were considered as the subplots $(0-10,10-20,20-30$, 30-40, and 40-50 cm). No fertilizer was applied.

Soil samples were collected in September 2007 (initial soil condition, prior to castor bean planting, and January 2008 (after 120 days of irrigation, at the time of harvest). Samples were collected at 0-10, 10-20, 20-30, 30-40 and 40-50 cm depths.

After air-drying, the soil samples were passed through a 2 $\mathrm{mm}$ seive. The soil analysis were carried out as described in EMBRAPA (1997). pH was determined in 1:2,5 soil water suspension. Organic matter determination was carried out as described by Walkley-Black method. Calcium and magnesium were extracted using $\mathrm{KCl} 1.0 \mathrm{~mol} \mathrm{~L}^{-1}$ and titration by EDTA. Potassium and sodium were extracted using $\mathrm{HCl} 0.05 \mathrm{~mol} \mathrm{~L}^{-1}$ and determined by flame photometry. Potential acidity was determined by means of $0.5 \mathrm{~mol} \mathrm{~L}^{-1}$ calcium acetate solutions at $\mathrm{pH}$ 7.0. Phosphorus was extracted using $\mathrm{HCl} 0.05 \mathrm{~mol} \mathrm{~L}^{-1}$ and was determined by colorimetry. The concentrations of available iron, manganese, copper, and zinc were determined by Mehlich-1 method.

The results of soil data were submitted to variance analysis. The statistical analysis were performed for each parameter and the variables showing results significantly different in the F-test $(\mathrm{P}<0.05)$ were submitted to mean comparison by Tukey's test $(\mathrm{P}<0.05)$.

\section{Results AND Discussion}

The higher $\mathrm{Ca}^{2+}$ concentrations (treatment means) were observed in T1, which can be explained by the combined action of addition via wastewater (Kiziloglu et al., 2008) and castor bean absorption by evapotranspiration, showing a statistical difference in comparison to other treatments (Table 4).

Table 4. Calcium $\left(\mathrm{Ca}^{2+}\right)$, magnesium $\left(\mathrm{Mg}^{2+}\right)$, sodium $\left(\mathrm{Na}^{+}\right)$and potassium $\left(\mathrm{K}^{+}\right)$of soil at different sampled depths, after the application of different water management strategies

\begin{tabular}{|c|c|c|c|c|c|}
\hline \multirow{2}{*}{$\begin{array}{l}\text { Depth } \\
\text { (cm) }\end{array}$} & \multicolumn{5}{|c|}{ Calcium $\left(\mathrm{mmol}_{\mathrm{c}} \mathrm{dm}^{-3}\right)$} \\
\hline & T1 & T2 & T3 & T4 & Mean \\
\hline $0-10$ & $29.83 \mathrm{aA}$ & $25.40 \mathrm{abA}$ & $20.33 \mathrm{cA}$ & $24.20 \mathrm{bcA}$ & $24.94 \mathrm{~A}$ \\
\hline $10-20$ & $22.77 \mathrm{aB}$ & $23.50 \mathrm{aAB}$ & $19.70 \mathrm{aA}$ & $22.00 \mathrm{aA}$ & $21.99 \mathrm{~B}$ \\
\hline $20-30$ & $22.03 \mathrm{aB}$ & $20.30 \mathrm{aAB}$ & $17.30 \mathrm{aA}$ & $20.13 \mathrm{aA}$ & 19.94 B \\
\hline $30-40$ & $24.07 \mathrm{aB}$ & $20.53 \mathrm{aAB}$ & $21.43 \mathrm{aA}$ & $20.63 \mathrm{aA}$ & $21.66 \mathrm{~B}$ \\
\hline $40-50$ & $24.37 \mathrm{aB}$ & $19.13 \mathrm{bB}$ & $18.87 \mathrm{bA}$ & $19.73 \mathrm{abA}$ & $20.52 \mathrm{~B}$ \\
\hline \multirow[t]{2}{*}{ Mean } & $24.61 \mathrm{a}$ & $21.77 \mathrm{~b}$ & $19.53 \mathrm{~b}$ & $21.34 \mathrm{~b}$ & - \\
\hline & \multicolumn{5}{|c|}{ Magnesium $\left(\mathrm{mmol}_{\mathrm{c}} \mathrm{dm}^{-3}\right)$} \\
\hline $0-10$ & $13.30 \mathrm{aA}$ & $15.77 \mathrm{aA}$ & $18.03 \mathrm{aA}$ & $16.73 \mathrm{aB}$ & $15.96 \mathrm{AB}$ \\
\hline $10-20$ & $14.80 \mathrm{abA}$ & $12.07 \mathrm{bA}$ & $14.43 \mathrm{abA}$ & $18.20 \mathrm{aB}$ & $14.87 \mathrm{~B}$ \\
\hline $20-30$ & $15.40 \mathrm{bA}$ & $14.37 \mathrm{bA}$ & $17.80 \mathrm{abA}$ & $22.67 \mathrm{aAB}$ & $17.56 \mathrm{AB}$ \\
\hline $30-40$ & $14.43 \mathrm{bA}$ & $14.10 \mathrm{bA}$ & $18.60 \mathrm{abA}$ & $22.17 \mathrm{aAB}$ & $17.32 \mathrm{AB}$ \\
\hline $40-50$ & $17.33 \mathrm{bA}$ & $17.67 \mathrm{bA}$ & $16.23 \mathrm{bA}$ & $24.93 \mathrm{aA}$ & $19.04 \mathrm{~A}$ \\
\hline \multirow[t]{2}{*}{ Mean } & $15.05 b$ & $14.79 \mathrm{~b}$ & $17.02 \mathrm{~b}$ & $20.94 \mathrm{a}$ & - \\
\hline & \multicolumn{5}{|c|}{ Sodium $\left(\mathrm{mmol}_{\mathrm{c}} \mathrm{dm}^{-3}\right)$} \\
\hline $0-10$ & $6.77 \mathrm{aD}$ & $5.23 \mathrm{aC}$ & $3.67 \mathrm{aB}$ & $4.33 \mathrm{aB}$ & $5.00 \mathrm{C}$ \\
\hline & $9.97 \mathrm{aCD}$ & $7.70 \mathrm{abBC}$ & 4.67 bB & $5.67 \mathrm{abAB}$ & $7.00 \mathrm{BC}$ \\
\hline $20-30$ & $13.67 \mathrm{aBC}$ & $8.77 \mathrm{bBC}$ & $7.00 \mathrm{bAB}$ & $6.00 \mathrm{bAB}$ & $8.86 \mathrm{~B}$ \\
\hline $30-40$ & $15.67 \mathrm{aAB}$ & $10.80 \mathrm{bAB}$ & $11.00 a b A$ & $8.33 \mathrm{bAB}$ & $11.45 \mathrm{~A}$ \\
\hline $40-50$ & $19.33 \mathrm{aA}$ & $13.47 \mathrm{bA}$ & $11.00 \mathrm{bA}$ & $9.33 \mathrm{bA}$ & $13.28 \mathrm{~A}$ \\
\hline \multirow[t]{2}{*}{ Mean } & $13.08 \mathrm{a}$ & $9.19 b$ & $7.47 \mathrm{~b}$ & $6.73 \mathrm{~b}$ & - \\
\hline & \multicolumn{5}{|c|}{ Potassium $\left(\mathrm{mmol}_{\mathrm{c}} \mathrm{dm}^{-3}\right)$} \\
\hline $0-10$ & $2.57 \mathrm{bA}$ & $1.97 \mathrm{cA}$ & $1.33 \mathrm{cA}$ & $3.07 \mathrm{aA}$ & $2.23 \mathrm{~A}$ \\
\hline $10-20$ & $1.37 \mathrm{bB}$ & $1.30 \mathrm{bB}$ & $1.03 \mathrm{bA}$ & $2.27 \mathrm{aB}$ & $1.49 \mathrm{~B}$ \\
\hline $20-30$ & $1.40 \mathrm{aB}$ & $1.20 \mathrm{aB}$ & $1.03 \mathrm{aA}$ & $1.33 \mathrm{aC}$ & $1.24 \mathrm{C}$ \\
\hline $30-40$ & $1.10 \mathrm{aB}$ & $1.07 \mathrm{aB}$ & $1.00 \mathrm{aA}$ & $1.07 \mathrm{aC}$ & $1.06 \mathrm{C}$ \\
\hline $40-50$ & $1.23 \mathrm{aB}$ & $1.03 \mathrm{aB}$ & $0.97 \mathrm{aA}$ & $1.03 \mathrm{aC}$ & $1.07 \mathrm{C}$ \\
\hline Mean & $1.53 \mathrm{~b}$ & $1.31 \mathrm{C}$ & $1.07 \mathrm{~d}$ & $1.75 \mathrm{a}$ & 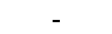 \\
\hline
\end{tabular}

For each parameter, same capital letters in the same column (different treatments) and same small letters in the same row (different sampling depth) do not differ by Tukey's test $(P<0.05)$

Although castor beans can absorb significant amounts of $\mathrm{Ca}^{2+}$ when grown in the presence of sewage sludge (Chiaradia et al., 2009), this nutrient is usually present in large amounts in wastewater from households, reaching in some cases concentrations higher than $\mathrm{Na}^{+}$, as observed in other studies (Medeiros et al., 2007; Sandri et al., 2009). These high levels in wastewater may lead to accumulation, even under crop cultivation, as found by Herpin et al. (2007).

In general lines, calcium was accumulated in the topsoil. There is a reduction of calcium concentration in the $10 \mathrm{~cm}$ depth below topsoil. The release of this cation by organic matter mineralization was retained in the surface layer (Table 4), and it may explain its higher concentration in this depth. The increase of $\mathrm{Ca}^{2+}$ in this layer, as result of wastewater irrigation, was reported by Leal et al. (2009a). On the other hand, Herpin et al. (2007) found an increase with depth, involving leaching, plant uptake and reaction of $\mathrm{Ca}^{2+}$ with carbonates and sulfates, which were present in the applied effluent.

The wastewater management had significant effect on the concentration of $\mathrm{Mg}^{2+}$ in the soil profile (Table 4), with higher values for T4. In T1, despite receiving the same water as T4, the added $\mathrm{Mg}^{2+}$ from the wastewater, usually present in low concentrations (Medeiros et al., 2007; Sandri et al., 2009; 
Leal et al., 2009a), was probably absorbed by the castor bean plants, since this nutrient is the $5^{\text {th }}$ most required nutrient for castor bean crop (Chiaradia et al., 2009). Supply water (T3) did not change the exchangeable magnesium neither calcium concentrations.

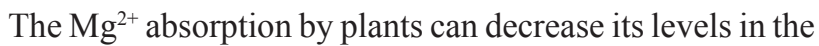
soil, even under wastewater irrigation, as verified by Fonseca et al. (2005) for Zea mays. Also, wastewater often contains solutes that can form magnesium precipitates, decreasing its availability. As there was no $\mathrm{Mg}^{2+}$ absorption in $\mathrm{T} 4$, this cation tended to increase its soil concentration. Increments in $\mathrm{Mg}^{2+}$ concentration due to the wastewater application were also observed by Sandri et al. (2009). However, Kiziloglu et al. (2008), Leal et al. (2009a), and Varallo et al. (2010) found no significant effect of wastewater irrigation on $\mathrm{Mg}^{2+}$ content in soil.

Only in T4, the deeper the soil profile, the higher was $\mathrm{Mg}^{2+}$ concentration, because $\mathrm{Mg}^{2+}$ was more subjected to leaching due to the absence of crop. In T1, T2, and T3, there were no changes in $\mathrm{Mg}^{2+}$ concentration with the depth. These results corroborate with Leal et al. (2009a) and Herpin et al. (2007) information, who detected no changes in the magnesium levels between layers from $10 \mathrm{~cm}$ to $40 \mathrm{~cm}$ in sugarcane and coffee crops, respectively. Sandri et al. (2009) found no differences between the $\mathrm{Mg}^{2+}$ concentrations in the depth of 0-10 and 10$20 \mathrm{~cm}$ for lettuce cultivation.

The wastewater irrigation increased $\mathrm{Na}^{+}$concentration across the profile, when compared with baseline values (Tables 2 and 4). Unlike other cations, $\mathrm{Na}^{+}$has a low affinity for soil exchange complex, mainly occurring in the soil solution, from where it can be leached (Leal et al., 2009a). Thus, the $\mathrm{Na}^{+}$ added from wastewater, usually present in high concentration (Kiziloglu et al., 2008), moves easily into the subsoil (Tarchouna et al., 2010), which justifies the increment of the cation levels as a function of the depth. Similar results were obtained by Heidarpour et al. (2007), who found accumulation of sodium in deeper layers due to leaching.

The lowest concentration in T4 is justified by the higher leaching, since there was no plant to consume part of the applied water.

Increments in $\mathrm{Na}^{+}$concentration after wastewater irrigation in agricultural soils are reported in studies of short and long term durations (Fonseca et al., 2005; Leal et al., 2009a). Besides the rate of water application and $\mathrm{Na}^{+}$content in the wastewater (Rusan et al., 2007), the absorption capacity of the crop (Sandri et al., 2009) and soil texture may have direct influence on the accumulation of this cation throughout the soil profile. Thus, crops with higher extraction capacity can reduce the levels of exchangeable sodium, and sandy soils tend to loose it more easily by leaching, due to reduced presence of negative charges, compared to clay soils (Sandri et al., 2009).

There was an increment in exchangeable $\mathrm{K}^{+}$in the wastewater irrigated plots, compared with those receiving supply water, in the following crescent order: $\mathrm{T} 2=\mathrm{T} 3<\mathrm{T} 1<$ T4 (Table 4), that may be related to the absence of castor bean to absorb potassium in $\mathrm{T} 4$.
In spite of relatively low concentration of this cation in wastewater (Arienzo et al., 2009), in many studies the increment in soil exchangeable $\mathrm{K}^{+}$has been reported after wastewater irrigation (Herpin et al., 2007; Heidarpour et al., 2007; Kiziloglu et al., 2008). However, these results are in disagreement with those obtained by Fonseca et al. (2005), who observed no significant effect and Varallo et al. (2010), who found a reduction in $\mathrm{K}^{+}$soil concentration after wastewater disposal.

The $\mathrm{K}^{+}$concentration in the surface layer $(0-10 \mathrm{~cm})$ of wastewater irrigated plots was significantly higher compared to the other layers. The potential for potassium accumulation in the soil for the wastewater disposal is high, due to low leaching capacity of this element (Arienzo et al., 2009). Also according to these authors, the potassium that is not absorbed by the plants is adsorbed by the soil, minimizing the leaching risk.

The much lower potassium concentration in comparison to $\mathrm{Mg}^{2+}$ and $\mathrm{Ca}^{2+}$ contents may have contributed to its accumulation, because in this condition, a preferential adsorption of $\mathrm{K}^{+}$occurs in the upper layer, which may explain the lower leaching of this cation in comparison to $\mathrm{Ca}^{2+}$ and $\mathrm{Mg}^{2+}$ (Ernani et al., 2006). Heidarpour et al. (2007) irrigated bermuda grass with wastewater and verified, at the end of the experiment, a higher potassium concentration in the $0-15$ $\mathrm{cm}$ layer, compared to $15-30 \mathrm{~cm}$. The soil $\mathrm{pH}$ was slightly acid in all depths before the irrigation treatments (Table 2). At the end of the experiment, T1 and T4 showed average $\mathrm{pH}$ values above 7.0, while T2 and T3 were still below 7.0, although all treatments were similar by the Tukey's test at 0.05 probability level. A significant increment was found in $\mathrm{pH}$ at $0-10$ and $10-20 \mathrm{~cm}$ of $\mathrm{T} 1, \mathrm{~T} 2$, and $\mathrm{T} 4$, compared with the others layers. In T3, there was no significant difference in $\mathrm{pH}$ among all the layers.

Small increments in $\mathrm{pH}$ were observed by Leal et al. (2009a) in the soil where sugarcane was grown with treated wastewater irrigation. Moreover, no changes in this attribute were observed by Varallo et al. (2010) after application of domestic wastewater in soil columns without cultivation.

The soil $\mathrm{pH}$ increased in $\mathrm{T} 3$, in comparison to the soil before irrigation. This can be attributed to the $\mathrm{pH}$ of the supply water (Table 3), which was higher than 7.0 and increased soil alkalinity. In the wastewater irrigation, the $\mathrm{pH}$ increment in the upper layer may be related to some factors, as: (i) the presence of exchangeable cations, (ii) the alkalinity of the water, (iii) the denitrification increment, which consumes one mole of $\mathrm{H}^{+}$ for each mole of denitrified $\mathrm{NO}_{3}{ }^{-}$, and (iv) the chelation of $\mathrm{Al}^{3+}$ by accumulated organic matter on the soil surface (Fonseca et al., 2005; Fonseca et al., 2007; Silva \& Mendonça, 2007). Small changes in $\mathrm{pH}$ (less than one unit) by the wastewater application are generally not able to directly affect the crops (Leal et al., 2009a).

The potential acidity $(\mathrm{H}+\mathrm{Al})$ significantly decreased in the soil of the wastewater irrigated plots, in comparison to those receiving supply water in the following crescent order: T4 $<\mathrm{T} 1<\mathrm{T} 2<\mathrm{T} 3$ (Table 5). The lowest values were observed in the upper layer of $\mathrm{T} 1, \mathrm{~T} 2$, and $\mathrm{T} 4$, which may be related to 
increased levels of organic matter in this layer (Table 5), that may chelate aluminum (Silva \& Mendonça, 2007). Reductions in the potential acidity have been found in soil irrigated with treated wastewater (Fonseca et al., 2005; Herpin et al., 2007; Leal et al., 2009a) and they are attributed to the increment of the exchangeable cations in the soil and the alkalinity of applied wastewater.

The wastewater irrigation affected the soil $\mathrm{P}$ content. The $\mathrm{P}$ concentrations in $\mathrm{T} 1, \mathrm{~T} 2$, and $\mathrm{T} 4$ were higher after the irrigations (Tables 2 and 5). Thus, wastewater increased the $P$ concentration in the analysed soil samples.

Certainly, the $\mathrm{P}$ input from wastewater was significant for the castor bean plants nutrition, decreasing the levels in soil samples from experimental units that contained this plants, since in $\mathrm{T} 1$ the levels were significantly lower than those of $\mathrm{T} 4$, despite having received only wastewater. Nevertheless, it appears that in some situations the P content in wastewater does not meet the castor bean nutritional demand, as verified by Souza et al. (2010), under field conditions in the State of Ceará, Northeastern Brazil.

The increment in soil $\mathrm{P}$ concentration due to the wastewater disposal is regularly observed, even in short duration experiments (Herpin et al., 2007; Kiziloglu et al., 2008), notably due to organic phosphorus increment. Experiments of long duration also found that the available $\mathrm{P}$ is higher in wastewater irrigated soils than in rainwater irrigated soils (Rusan et al., 2007).

Table 5. Active acidity $(\mathrm{pH})$, potential acidity $(\mathrm{H}+\mathrm{Al})$, phosphorus and soil organic matter (SOM) at different depths of sampling, after the application of different water management strategies

\begin{tabular}{cccccc}
\hline Depth & \multicolumn{5}{c}{ pH } \\
\cline { 2 - 6 } (cm) & T1 & T2 & T3 & T4 & Mean \\
$0-10$ & $7.40 \mathrm{aA}$ & $7.00 \mathrm{aA}$ & $7.07 \mathrm{aA}$ & $7.33 \mathrm{aA}$ & $7.20 \mathrm{~A}$ \\
$10-20$ & $7.57 \mathrm{aA}$ & $6.93 \mathrm{bAB}$ & $6.77 \mathrm{bA}$ & $7.23 \mathrm{abA}$ & $7.12 \mathrm{~A}$ \\
$20-30$ & $7.27 \mathrm{aA}$ & $6.60 \mathrm{bBC}$ & $6.80 \mathrm{abA}$ & $6.97 \mathrm{abAB}$ & $6.91 \mathrm{~B}$ \\
$30-40$ & $6.67 \mathrm{aB}$ & $6.27 \mathrm{aC}$ & $6.80 \mathrm{aA}$ & $6.80 \mathrm{aB}$ & $6.63 \mathrm{C}$ \\
$40-50$ & $6.37 \mathrm{aB}$ & $6.23 \mathrm{aC}$ & $6.77 \mathrm{aA}$ & $6.77 \mathrm{aB}$ & $6.53 \mathrm{C}$ \\
Mean & $7.05 \mathrm{aB}$ & $6.61 \mathrm{a}$ & $6.84 \mathrm{a}$ & $7.02 \mathrm{a}$ & - \\
\hline \multicolumn{5}{c}{$\mathrm{H}+\mathrm{Al}$} & $\left(\mathrm{mmol}_{\mathrm{c}} \mathrm{dm}^{-3}\right)$ \\
$0-10$ & $0.97 \mathrm{cD}$ & $5.00 \mathrm{bC}$ & $8.10 \mathrm{aA}$ & $1.00 \mathrm{cB}$ & $3.77 \mathrm{C}$ \\
$10-20$ & $1.83 \mathrm{bCD}$ & $4.67 \mathrm{bC}$ & $8.83 \mathrm{aA}$ & $2.00 \mathrm{bB}$ & $4.33 \mathrm{C}$ \\
$20-30$ & $4.27 \mathrm{bBC}$ & $8.10 \mathrm{aAB}$ & $9.37 \mathrm{aA}$ & $3.17 \mathrm{bAB}$ & $6.22 \mathrm{~B}$ \\
$30-40$ & $7.17 \mathrm{abAB}$ & $7.17 \mathrm{abBC}$ & $9.37 \mathrm{aA}$ & $5.50 \mathrm{bA}$ & $7.30 \mathrm{AB}$ \\
$40-50$ & $8.27 \mathrm{abA}$ & $10.47 \mathrm{aA}$ & $9.63 \mathrm{aA}$ & $5.50 \mathrm{bA}$ & $8.47 \mathrm{~A}$ \\
Mean & $4.50 \mathrm{C}$ & $7.08 \mathrm{~b}$ & $9.06 \mathrm{a}$ & $3.43 \mathrm{C}$ & - \\
\hline \multicolumn{5}{c}{$\mathrm{Phosphorus}\left(\mathrm{mg} \mathrm{dm}{ }^{-3}\right)$} \\
$0-10$ & $19.83 \mathrm{bA}$ & $10.60 \mathrm{cA}$ & $5.37 \mathrm{dA}$ & $29.10 \mathrm{aA}$ & $16.22 \mathrm{~A}$ \\
$10-20$ & $11.33 \mathrm{bB}$ & $7.27 \mathrm{cAB}$ & $4.40 \mathrm{cA}$ & $18.20 \mathrm{aB}$ & $10.30 \mathrm{~B}$ \\
$20-30$ & $4.63 \mathrm{abC}$ & $4.20 \mathrm{abB}$ & $2.90 \mathrm{bA}$ & $7.37 \mathrm{aC}$ & $4.77 \mathrm{C}$ \\
$30-40$ & $4.37 \mathrm{aC}$ & $4.27 \mathrm{aB}$ & $4.37 \mathrm{aA}$ & $6.27 \mathrm{aC}$ & $4.82 \mathrm{C}$ \\
$40-50$ & $5.13 \mathrm{aC}$ & $5.63 \mathrm{aB}$ & $4.33 \mathrm{aA}$ & $6.50 \mathrm{aC}$ & $5.40 \mathrm{C}$ \\
Mean & $9.06 \mathrm{~b}$ & $6.39 \mathrm{C}$ & $4.27 \mathrm{c}$ & $13.49 \mathrm{a}$ & - \\
\hline \multicolumn{5}{c}{ Soil organic matter $\left(\mathrm{g} \mathrm{kg}{ }^{-1}\right)$} \\
$0-10$ & $4.97 \mathrm{aA}$ & $4.27 \mathrm{abA}$ & $3.87 \mathrm{bA}$ & $4.60 \mathrm{abA}$ & $4.42 \mathrm{~A}$ \\
$10-20$ & $4.00 \mathrm{aAB}$ & $4.17 \mathrm{aA}$ & $4.07 \mathrm{aA}$ & $3.80 \mathrm{aAB}$ & $4.01 \mathrm{~A}$ \\
$20-30$ & $2.90 \mathrm{aC}$ & $3.30 \mathrm{aAB}$ & $3.37 \mathrm{aA}$ & $3.27 \mathrm{aB}$ & $3.21 \mathrm{~B}$ \\
$30-40$ & $3.07 \mathrm{aBC}$ & $3.27 \mathrm{aAB}$ & $3.17 \mathrm{aA}$ & $3.77 \mathrm{aAB}$ & $3.32 \mathrm{~B}$ \\
$40-50$ & $3.40 \mathrm{aBC}$ & $3.03 \mathrm{aB}$ & $3.30 \mathrm{aA}$ & $3.60 \mathrm{aAB}$ & $3.33 \mathrm{~B}$ \\
Mean & $3.67 \mathrm{a}$ & $3.61 \mathrm{a}$ & $3.55 \mathrm{a}$ & $3.81 \mathrm{a}$ & - \\
\hline
\end{tabular}

For each parameter, same capital letters in the same column (different treatments) and same small letters in the same row (different sampling depth) do not differ by Tukey's test $(P<0.05)$
The highest values of available $\mathrm{P}$ observed in the soil surface layer in T1, T2, and T4 (Table 5) corroborate the results obtained by Rusan et al. (2007) and Herpin et al. (2007) and can be attributed to several mechanisms, as the following: (i) increased P supply from wastewater, which contains this nutrient (Medeiros et al., 2007), (ii) mineralization of organic matter added by wastewater, which accumulates in the soil surface layer (Kiziloglu et al., 2008), (iii) P adsorption near the point of wastewater application, since this is a very immobile element, and (iv) possible $\mathrm{P}$ desorption or dissolution due to pH increase (Herpin et al., 2007). Liang et al. (2010) found that soil from rural areas of China with mineralogy similar to Fluvic Neosol (with high amount of kaolinite) showed high P content in wastewater due to the low adsorption capacity of the soil.

The organic matter content presented significant differences for treatment effect only in the surface layer. In general, it seems that there are lower levels of organic matter at depth, probably due to the short duration of the experiment. So, a longer wastewater application could favor the translocation of organic compounds to deeper layers, as verified by Rusan et al. (2007).

The levels of verified organic matter in the superficial layer, especially in wastewater treatments (T1, T2, and T4), corroborate the results obtained by Rusan et al. (2007), Herpin et al. (2007), and Sandri et al. (2009) in wastewater irrigation in soils cultivated with forage crops, pasture, and coffee, respectively. These results suggest very low leaching of carbon in wastewater irrigated soils, especially in short duration experiments (Herpin et al., 2007).

On the other hand, it is reported that wastewater irrigation in tropical soils does not change organic matter (Leal et al., 2010) or even decreases it (Duarte et al., 2008), which may be related to short duration period of the experiments or to a higher mineral $\mathrm{N}$ concentration, that increases microbial activity.

Organic matter is one of the most important soil quality indicators, especially with regard to nutrient cycling. Its presence is important for metal mobility control and to improve soil structure (Silva \& Mendonça, 2007). Thus, the increment of its concentration in the soil surface layer is important and should be considered in wastewater reuse designs.

No significant effect of water source has been verified on the available $\mathrm{Fe}^{2+}$ and $\mathrm{Zn}^{2+}$ concentrations in the soil samples, but there were significant differences for $\mathrm{Mn}^{2+}$ and $\mathrm{Cu}^{2+}$ concentrations (Table 6). The results for $\mathrm{Fe}^{2+}$ and $\mathrm{Zn}^{2+}$ are in accordance with those obtained by Xu et al. (2010) in short duration (three years) wastewater irrigation, suggesting that these wastewater metal concentrations are not high enough to cause environmental impacts in experiments of such duration.

The $\mathrm{Cu}^{2+}$ concentration was significantly lower in $\mathrm{T} 3$ than in T1, T2, and T4 (treatment means). Castor bean absorbs this ion, with no restitution by wastewater, as occurred in $\mathrm{T} 1$ and $\mathrm{T} 2$ and as verified by Liu et al. (2005), during rice, wheat, corn, and vegetables grown. Figueroa et al. (2008) found that the castor bean plant is highly demanding to this micronutrient. The ranges of $\mathrm{Cu}^{2+}$ concentration are in agreement with those observed by Varallo et al. (2010), but are very low compared to the ranges verified by Sandri et al. (2009), even though the both researches were carried out with wastewater in Oxisols. 
Table 6. Iron, manganese, copper, and zinc concentrations in soil at different depths after irrigation with different water sources

\begin{tabular}{|c|c|c|c|c|c|}
\hline \multirow{2}{*}{$\begin{array}{l}\text { Depth } \\
\text { (cm) }\end{array}$} & \multicolumn{5}{|c|}{$\mathrm{Fe}\left(\mathrm{mg} \mathrm{kg}^{-1}\right)$} \\
\hline & T1 & T2 & T3 & T4 & Mean \\
\hline $0-10$ & $205.90 \mathrm{abAB}$ & $226.67 \mathrm{aA}$ & $161.87 \mathrm{bA}$ & $178.27 \mathrm{abA}$ & $193.17 \mathrm{~A}$ \\
\hline & $224.33 \mathrm{aA}$ & $190.47 \mathrm{abAB}$ & $164.60 \mathrm{abA}$ & $159.77 \mathrm{bAB}$ & $184.79 \mathrm{~A}$ \\
\hline & $152.73 \mathrm{aB}$ & $147.73 \mathrm{aB}$ & $132.17 \mathrm{aA}$ & $130.53 \mathrm{aAB}$ & $140.79 \mathrm{~B}$ \\
\hline & $147.73 \mathrm{aB}$ & $156.40 \mathrm{aB}$ & $119.33 \mathrm{aA}$ & 107.73aB & $132.80 \mathrm{~B}$ \\
\hline $40-50$ & $149.83 \mathrm{aB}$ & $173.83 \mathrm{aAB}$ & $111.53 \mathrm{aA}$ & $120.00 \mathrm{aAB}$ & $138.80 \mathrm{~B}$ \\
\hline \multirow[t]{2}{*}{ Mean } & $176.11 \mathrm{a}$ & $179.02 \mathrm{a}$ & $137.90 \mathrm{a}$ & $139.26 \mathrm{a}$ & - \\
\hline & \multicolumn{5}{|c|}{$\mathrm{Mn}\left(\mathrm{mg} \mathrm{kg}^{-1}\right)$} \\
\hline $0-10$ & $48.33 \mathrm{aA}$ & $47.92 \mathrm{aA}$ & $34.84 \mathrm{bAB}$ & $37.33 \mathrm{abA}$ & $42.11 \mathrm{~A}$ \\
\hline $10-20$ & $47.70 \mathrm{aA}$ & $43.99 \mathrm{aAB}$ & $3 \mathrm{aA}$ & $35.97 \mathrm{aA}$ & $42.10 \mathrm{~A}$ \\
\hline $20-30$ & $40.14 \mathrm{aAB}$ & $35.28 \mathrm{abB}$ & $3 a b B$ & $25.07 \mathrm{bB}$ & $32.45 \mathrm{~B}$ \\
\hline $30-40$ & $37.00 \mathrm{aB}$ & $36.41 \mathrm{aB}$ & $28.66 \mathrm{abB}$ & $23.49 \mathrm{bB}$ & $31.39 \mathrm{~B}$ \\
\hline $40-50$ & $35.74 \mathrm{aB}$ & $34.70 \mathrm{aB}$ & $26.67 \mathrm{aB}$ & $29.66 \mathrm{aAB}$ & $31.69 \mathrm{~B}$ \\
\hline \multirow[t]{2}{*}{ Mean } & $41.78 \mathrm{a}$ & $39.66 a b$ & $32.05 a b$ & $3030 \mathrm{~h}$ & - \\
\hline & \multicolumn{5}{|c|}{$\mathrm{Cu}\left(\mathrm{mg} \mathrm{kg}^{-1}\right)$} \\
\hline 10 & $0.90 \mathrm{aA}$ & $0.94 \mathrm{aA}$ & $0.82 \mathrm{aA}$ & 0.8 & $0.89 \mathrm{~A}$ \\
\hline $10-20$ & $0.87 \mathrm{abA}$ & $1.00 \mathrm{aA}$ & $\mathrm{bA}$ & $0.93 \mathrm{abA}$ & $0.86 \mathrm{~A}$ \\
\hline $20-30$ & $0.93 \mathrm{aA}$ & $0.83 \mathrm{aA}$ & $5 \mathrm{aA}$ & $0.82 \mathrm{aA}$ & $0.83 \mathrm{~A}$ \\
\hline $30-40$ & $0.85 a b A$ & $1.13 \mathrm{aA}$ & $0.61 \mathrm{bA}$ & $1.09 \mathrm{aA}$ & $0.92 \mathrm{~A}$ \\
\hline $40-50$ & $0.85 \mathrm{aA}$ & $0.94 \mathrm{aA}$ & $0.77 \mathrm{aA}$ & $0.87 \mathrm{aA}$ & $0.86 \mathrm{~A}$ \\
\hline Mean & $0.88 a b$ & $0.97 \mathrm{a}$ & $0.71 \mathrm{~b}$ & $0.92 \mathrm{a}$ & - \\
\hline \multicolumn{6}{|c|}{$\mathrm{Zn}\left(\mathrm{mg} \mathrm{kg}^{-1}\right)$} \\
\hline $0-10$ & $2.79 \mathrm{aA}$ & $2.55 \mathrm{aA}$ & $2.29 \mathrm{aA}$ & $3.75 \mathrm{aA}$ & $2.84 \mathrm{~A}$ \\
\hline $10-20$ & $2.37 \mathrm{aA}$ & $2.42 \mathrm{aA}$ & $1.90 \mathrm{aA}$ & $2.58 \mathrm{aAB}$ & $2.32 \mathrm{AB}$ \\
\hline $20-30$ & $1.74 \mathrm{aA}$ & $1.72 \mathrm{aA}$ & $1.35 \mathrm{aA}$ & $2.17 \mathrm{aB}$ & $1.74 \mathrm{~B}$ \\
\hline $30-40$ & $1.42 \mathrm{aA}$ & $2.29 \mathrm{aA}$ & $1.28 \mathrm{aA}$ & $1.51 \mathrm{aB}$ & $1.62 \mathrm{~B}$ \\
\hline $40-50$ & $1.71 \mathrm{aA}$ & $1.95 \mathrm{aA}$ & $1.50 \mathrm{aA}$ & $2.14 \mathrm{aB}$ & $1.82 \mathrm{~B}$ \\
\hline Mean & $2.00 \mathrm{a}$ & $2.19 \mathrm{a}$ & $1.66 \mathrm{a}$ & $2.43 \mathrm{a}$ & \\
\hline
\end{tabular}

For each parameter, same capital letters in the same column (different treatments) and same small letters in the same row (different sampling depth) do not differ by Tukey's test $(P<0.05)$

The lower mean concentration of $\mathrm{Mn}^{2+}$ was observed in $\mathrm{T} 4$ (treatment means), probably due to the formation of precipitates with carbonates and phosphates which were added by wastewater and released during the organic matter mineralization, making manganese unavailable, because these anions have a high affinity to chelate this metal cation (He et al., 2010). In T1, these mechanisms probably had a lower magnitude, due to castor bean absorption of such responsible ions $\left(\mathrm{H}_{2} \mathrm{PO}_{4}^{-}, \mathrm{Mg}^{2+}\right.$, and $\mathrm{Cu}^{2+}$ ), minimizing the chelation, increasing the non-specific adsorption and the $\mathrm{Mn}^{2+}$ concentration.

In general terms, it was observed that all studied cationic micronutrients present a low soil mobility and tend to accumulate in the upper layers. According to some other studies (Rusan et al., 2007; Kiziloglu et al., 2008; Xu et al., 2010), the mobility of these elements to deeper layers in wastewater irrigated soils is not common, because it is closely related to the organic matter distribution in the soil profile.

\section{Conclusions}

1. Despite the short duration of the experiment, there were significant changes in soil chemical attributes due to the wastewater application.

2. The wastewater application in the castor bean crop increased phosphorous, calcium, potassium, and organic matter concentrations, mainly in the superficial layer of soil.

3. The disposal of wastewater on Fluvic Neosol not cultivated with castor bean increased the magnesium concentration in soil
4. The wastewater irrigation did not change $\mathrm{pH}$, neither iron and zinc concentration in soil.

\section{ACKNOWLEDGMENTS}

This work was supported by CNPq (Process No. 552868/2007-8) and EMBRAPA (02.09.07.000.00.00). The authors would like to thanks João Paulo Saraiva Morais for English the grammar and spelling review.

\section{Literature Cited}

APHA - American Public Health Association. Standard Methods for the Examination for Water and Wastewater, 20.ed. Washington: American Public Health Association, 1999. 1325p.

Arienzo, M.; Christen, E. W.; Quayle, W.; Kumar, A. A review of the fate of potassium in the soil-plant system after land application of wastewaters. Journal of Hazardous Materials, v.164, p.415-422, 2009.

Chiaradia, J. J.; Chiba, M. K.; Andrade, C. A.; Oliveira, C.; Lavorenti, A. Produtividade e nutrição de mamona cultivada em área de reforma de canavial tratada com lodo de esgoto. Revista Brasileira de Ciência do Solo, v.33, p.701-709, 2009.

Corwin, D. L.; Bradford, S. A. Environmental impacts and sustainability of degraded water reuse. Journal of Environmental Quality, v.37, p.1-7, 2008.

Duan, R.; Sheppard, C. D.; Fedler, C. B. Short-term effects of wastewater land application on soil chemical properties. Water, Air and Soil Pollution, v.211, p.165$176,2010$.

Duarte, A. S.; Airoldi, R. P. S.; Folegatti, M. V.; Botrel, T. A.; Soares, T. M. Efeitos da aplicação de efluente tratado no solo: $\mathrm{pH}$, matéria orgânica, fósforo e potássio. Revista Brasileira de Engenharia Agrícola e Ambiental, v.12, p.302310, 2008.

EMBRAPA - Empresa Brasileira de Pesquisa Agropecuária. Manual de métodos de análise de solo. 2.ed. Rio de Janeiro: Embrapa CNPS, 1997. 212p. Documentos, 1.

EMBRAPA - Empresa Brasileira de Pesquisa Agropecuária. Sistema brasileiro de classificação de solos. 2.ed. Rio de Janeiro: EMBRAPA, 2006. 306p.

Ernani, P. R.; Miquelluti, A.; Fontoura, S. M. V.; Kaminski, J.; Almeida, J. A. Downward movement of soil cátions in highly weathered soils caused by addition of gypsum. Communications in Soil Science and Plant Analysis, v.37, p.571-586, 2006.

Figueroa, J. A. L.; Wrobel, K.; Afton, S.; Caruso, J. A.; Corona, J. F. G.; Wrobel, K. Effect of some heavy metals and soil humic substances on the phytochelatin production in wild plants from silver mine areas of Guanajuato, Mexico. Chemosphere, v.70, p.2084-2091, 2008.

Fonseca, A. F.; Herpin, U.; Paula, A. M.; Victoria, R. L.; Melfi, A. J. Agricultural use of treated sewage effluents: agronomical-environmental implications and perspectives for Brazil. Scientia Agricola, v.64, p.194-209, 2007. 
Fonseca, A. F.; Melfi, A. J.; Montes, C. R. Maize growth and changes in soil fertility after irrigation with treated sewage effluent. II. soil acidity, exchangeable cations, and sulfur, boron, and heavy metals availability. Communications in Soil Science and Plant Analysis, v.36, p.1983-2003, 2005.

He, Z. L.; Shentu, J.; Yang, X. E. Manganese and selenium. In P. S. Hooda (ed.). Trace elements in soils. London: Wiley, 2010. Cap.20, p.481-496.

Heidarpour, M.; Fard, B. M.; Koupai, J. A. The effects of treated wastewater on soil chemical properties using subsurface and surface irrigation methods. Agricultural Water Management, v.90, p.87-94, 2007.

Herpin, U.; Gloaguen, T. V.; Fonseca, A. F.; Montes, C. R.; Mendonça, F. C.; Piveli, R. P.; Breulmann, G.; Forti, M. C.; Melfi, A. J. Chemical effects on soil-plant system in a secondary treated wastewater irrigated coffee plantation $-\mathrm{a}$ pilot field study in Brazil. Agriculture Water Management, v.89, p.105-115, 2007.

Kiziloglu, F. M.; Turan, M.; Sahin, U.; Kuslu, Y.; Dursun, A. Effects of untreated and treated wastewater irrigation on some chemical properties of cauliflower (Brassica olerecea L. var. botrytis) and red cabbage (Brassica olerecea L. var. rubra) grown on calcareous soil in Turkey. Agricultural Water Management, v.95, p.716-724. 2008.

Leal, R. M. P.; Firme, L. P.; Herpin, U.; Fonseca, A. F.; Montes, C. R.; Dias, C. T. S.; Melfi, A. J. Carbon and nitrogen cycling in a tropical Brazilian soil cropped with sugarcane and irrigated with wastewater. Agricultural Water Management, v.97, p.271-276, 2010.

Leal, R. M. P.; Firme, L. P.; Montes, C. R.; Melfi, A. J.; Piedade, S. M. S. Soil exchangeable cátions, sugarcane production and nutrient uptake after wastewater irrigation. Scientia Agricola, v.66, p.242-249, 2009a.

Leal, R. M. P.; Herpin, U.; Fonseca, A. F.; Firme, L. P.; Montes, C. R.; Melfi, A. J. Sodicy and salinity in a Brazilian Oxisol cultivated with sugarcane irrigated with wastewater. Agriculture Water Management, v.96, p.307-396, 2009 b.

Liang, H.; Liu, J.; Wei, Y.; Guo, X. Evaluation of phosphorus removal from wastewater by soils in rural areas in China. Journal of Environmental Sciences, v.22, p.15-22, 2010.
Liu, W. H.; Zhao, J. Z.; Ouyang, Z. Y.; Soderlund, L.; Liu, G. $H$. Impact of sewage irrigation on heavy metal distribution and contamination in Beijing, China. Environmental International, v.31, p.805-812, 2005.

Medeiros, S. S.; Soares, F. A. L.; Gheyi, H. R.; Fernandes, P. D. Uso de água residuária de origem urbana no cultivo de gérberas: Efeito nos componentes de produção. Engenharia Agrícola, v.27, p.569-578, 2007.

Rusan, M. J. M.; Hinnawi, S.; Rousan, L. Long term effect of wastewater irrigation of forage crops on soil and plant quality parameters. Desalination, v.215, p.143-152, 2007.

Sandri, D.; Matsura, E. E.; Testezlaf, R. Alteração química do solo irrigado por aspersão e gotejamento subterrâneo e superficial com água residuária. Revista Brasileira de Engenharia Agrícola e Ambiental, v.13, p.775-764, 2009.

Silva, I. R.; Mendonça, E. S. Matéria orgânica do solo. In Novais, R. F.; Alvarez V., V. H.; Barros, N. F.; Fontes, R. L. F.; Cantarutti, R. B.; Neves, J. C. (ed.). Fertilidade do Solo. Viçosa: SBCS, 2007. Cap.6, p.275-374.

Souza, N. C.; Mota, S. B.; Bezerra, F. M. L.; Aquino, B. F.; Santos, A. B. Produtividade da mamona irrigada com esgoto doméstico tratado. Revista Brasileira de Engenharia Agrícola e Ambiental, v.14, p.478-484, 2010.

Tarchouna, L. G.; Merdy, P.; Raynaud, M.; Pfeifer, H. R.; Lucas, Y. Effects of long-term irrigation with treated wastewater. Part 1: Evolution of soil physico-chemical properties, Applied Geochemistry, v.25, p.1703-1710, 2010.

Tozé, S. Reuse of effluent water - Benefits and risks. Agricultural Water Management, v.80, p.147-159, 2006.

Varallo, A. C. T.; Carvalho, L.; Santoro, B. L.; Souza, C. F. Alterações nos atributos de um Latossolo VermelhoAmarelo irrigado com água de reúso. Revista Brasileira de Engenharia Agrícola e Ambiental, v.14, p.372-377, 2010.

Xu, J.; Wu, L.; Chang, A. C.; Zhang, Y. Impact of long-term reclaimed wastewater irrigation on agricultural soils: A preliminary assessment. Journal of Hazardous Materials, v.183, p.780-786, 2010. 